\title{
Ogłoszenie upadłości posiadacza odpadów a obowiązek ich usunięcia z miejsca nieprzeznaczonego do ich składowania w świetle art. 26 ust. 1 i 2 ustawy z dnia 14 grudnia 2012 r. o odpadach
}

Wstęp

Zgodnie z art. 3 ust. 1 pkt 19 ustawy z dnia 14 grudnia 2012 r. o odpadach ${ }^{1}$ posiadaczem odpadów jest ich wytwórca lub osoba fizyczna, osoba prawna i jednostka organizacyjna bez nadanej osobowości prawnej będąca w posiadaniu odpadów. Przepis ten ustanawia również domniemanie, wedle którego władający powierzchnią ziemi jest posiadaczem odpadów znajdujących się na nieruchomości. W myśl unormowania $\mathrm{z}$ art. 26 ust. 1 i 2 u.o. posiadacz odpadów ma obowiązek niezwłocznego usunięcia odpadów z miejsca nieprzeznaczonego do ich składowania lub magazynowania, a w razie niewykonania przez niego tego obowiązku wójt, burmistrz lub prezydent miasta wydadzą decyzję nakazującą posiadaczowi odpadów ich usunięcie. Kto staje się podmiotem odpowiedzialnym za realizację powyższego obowiązku, w sytuacji gdy w stosunku do dotychczasowego posiadacza zostanie wydane postanowienie o ogłoszeniu upadłości, a zarząd jego majątkiem przejmie syndyk? Czy okoliczność, że odpady znalazły się $\mathrm{w}$ miejscu nieprzeznaczonym do ich składowania lub ma-

\footnotetext{
1 Dz.U. 2020, poz. 797; dalej: u.o.
} 
gazynowania przed ogłoszeniem upadłości bądź po nim, wpływa na podmiot obowiązany do ich usunięcia? Jak wygląda postępowanie w sprawie wydania decyzji, o której mowa w art. 26 ust. 2 u.o.?

\section{Podmiot odpowiedzialny za wykonanie obowiązku, o którym mowa w art. 26 ust. 1 u.o.}

Jak już zostało powiedziane, zgodnie z treścią art. 3 ust. 1 pkt 19 u.o. posiadaczem odpadów jest ich wytwórca lub osoba będąca w ich posiadaniu. Wątpliwości nie budzi definicja wytwórcy odpadów, gdyż art. 3 ust. 1 pkt 32 u.o. wskazuje, że jest nim każdy, kogo działalność lub bytowanie powoduje powstawanie odpadów (pierwotny wytwórca odpadów), oraz każdy, kto przeprowadza wstępną obróbkę, mieszanie lub inne działania powodujące zmianę charakteru lub składu tych odpadów. Wytwórcą odpadów powstających w wyniku świadczenia usług w zakresie budowy, rozbiórki, remontu obiektów, czyszczenia zbiorników lub urządzeń oraz sprzątania, konserwacji i napraw jest podmiot, który świadczy usługę, chyba że umowa o świadczenie usługi stanowi inaczej. Oprócz wytwórcy odpadów ich posiadaczem jest również każdy inny podmiot będący w ich posiadaniu, niezależnie od tego, czyli chodzi o osobę fizyczną, czy o osobę prawną lub jednostkę organizacyjną nieposiadającą osobowości prawnej. Wyżej wymienione podmioty muszą być w posiadaniu odpadów, aby odpowiadały za gospodarowanie nimi zgodnie z przepisami.

Przepisy regulujące posiadanie zawarte są $\mathrm{w}$ art. 336-352 ustawy $\mathrm{z}$ dnia 23 kwietnia 1964 r. - Kodeks cywilny². Zgodnie z uregulowaniem z k.c. posiadaczem odpadów będzie zarówno ten, kto odpadami włada jako właściciel (tzw. posiadacz samoistny), jak i ten, kto nimi faktycznie włada jako użytkownik, zastawnik, najemca, dzierżawca lub mający inne prawo, z którym łączy się określone władztwo nad cudzymi odpadami (tzw. posiadacz zależny) ${ }^{3}$. Bardziej skomplikowana wydaje się wykładnia domniemania prawnego wynikającego $\mathrm{z}$ art. 3 ust. 1 pkt 19 u.o. Zgodnie z treścią tego unormowania trzeba przyjąć, że posiadaczem odpadów jest osoba władająca powierzchnią ziemi, na której zgromadzone są odpady. „Zauważyć jednak należy, że ustawa o odpadach nie zawiera definicji pojęcia »władającego powierzchnią ziemi«. Pojęcie to definiuje natomiast ustawa $\mathrm{z}$ dnia $27 \mathrm{kwietnia} 2001 \mathrm{r}$. - Prawo ochrony środowiska [...]. Stosownie do art. 3 pkt 44 tej ostatniej ustawy pod pojęciem »władającego

${ }^{2}$ Dz.U. 2020, poz. 1740; dalej: k.c.

${ }^{3}$ Wyrok WSA w Poznaniu z dnia 12 lutego 2020 r., sygn. IV SA/Po 1028/19, Legalis nr 2297202. 
powierzchnią ziemi rozumie się właściciela nieruchomości, a jeżeli w ewidencji gruntów i budynków prowadzonej na podstawie ustawy - Prawo geodezyjne i kartograficzne ujawniono inny podmiot władający gruntem - podmiot ujawniony jako władający«. Za zastosowaniem powyższej definicji na gruncie ustawy o odpadach przemawia chociażby wykładnia systemowa"4.

Skoro, jak wskazano, posiadaczem odpadów może być osoba fizyczna, prawna, jednostka organizacyjna nieposiadająca osobowości prawnej, to zachodzi możliwość, że zostanie ogłoszona ich upadłośćs. W takiej sytuacji konieczne okazuje się ustalenie, kto staje się odpowiedzialny za usunięcie odpadów. Zgodnie $\mathrm{z}$ art. 75 ust. 1 ustawy z dnia 28 lutego 2003 r. - Prawo upadłościowe ${ }^{6}-$ $\mathrm{z}$ dniem ogłoszenia upadłości upadły całkowicie traci prawo zarządu mieniem wchodzącym do masy upadłości i rozporządzania nim oraz możliwość korzystania z niego. „Tym samym następuje odjęcie upadłemu wszystkich zewnętrznych przymiotów prawa, które mu służy"7. Natomiast nadal będzie on posiadał odpowiedni tytuł prawny, gdyż mimo powyższego pozostaje właścicielem, najemcą czy użytkownikiem wieczystym, z zastrzeżeniem, że nie może wykonywać żadnego z owych praw w jakikolwiek sposób, chociażby najmniej istotny. Od tego momentu nie może także rozporządzać mieniem stanowiącym masę upadłości. Unormowanie to dotyczy wszelkich czynności prawnych, niezależnie od tego, czy przekraczają zwykły zarząd, czy też nie. Ewentualne rozporządzenie takim mieniem jest bezwzględnie nieważne. Upadły nie może również korzystać z posiadanego mienia, z wyłączeniem okoliczności opisanych $\mathrm{w}$ art. 75 ust. 2 pr.up., a pożytki uzyskane z przedmiotu prawa własności stanowią masę upadłości, nie zaś majątek upadłego. Nie może on zatem wykonywać uprawnień wynikających z prawa własności $\mathrm{w}$ rozumieniu art. 140 k.c. ${ }^{8}$

Zgodnie z art. 51 pr.up. sąd, uwzględniwszy złożony wniosek o ogłoszenie upadłości, wydaje postanowienie o jej ogłoszeniu, które co do zasady jest skuteczne i wykonalne z dniem wydania; dla jego wykonalności i skuteczności nie ma znaczenia prawomocność postanowienia o ogłoszeniu upadłości ${ }^{9}$. Pomimo wieloletniego sporu w piśmiennictwie, czy skutki ogłoszenia upadłości należy liczyć od początku dnia, czy też od jego końca - obecnie przeważa ten pierwszy pogląd ${ }^{10}$. Za uznaniem, że owe skutki biegną od początku dnia (tj. od godzi-

${ }^{4}$ Wyrok WSA w Łodzi z dnia 19 czerwca 2018 r., sygn. II SA/Ld 338/18, LEX nr 2513943.

${ }_{5}^{5}$ Oczywiście po spełnieniu przesłanek wskazanych w ustawie z dnia 28 lutego 2003 r. Prawo upadłościowe, których z uwagi na przedmiot artykułu nie trzeba tu analizować.

${ }^{6}$ Dz.U. 2017, poz. 2344; dalej: pr.up.

7 P. Zimmerman: Prawo upadłościowe. Prawo restrukturyzacyjne. Komentarz. Wyd. 6. Legalis 2020.

${ }^{8}$ P. Janda: Prawo upadtościowe. Komentarz. Wyd. 2. LEX 2020, art. 1.

9 S. Gurgul: Prawo upadtościowe. Prawo restrukturyzacyjne. Komentarz. Wyd. 12. Legalis 2020; P. Janda: Prawo upadtościowe...

${ }^{10}$ R. Adamus: Prawo upadłościowe. Komentarz. Wyd. 2. Wydawnictwo C.H. Beck, Warszawa 2018, s. 202-205; P. Zimmerman, Prawo upadtościowe...; D. Chrapoński: Wyłaczenia 
ny 0.00 ), opowiedział się w swoich orzeczeniach Sąd Najwyższy ${ }^{11}$. Stanowisko to znajduje wsparcie również w wykładni gramatycznej art. 52 pr.up., w którym mowa o dacie, a ta rozpoczyna się wraz z początkiem dnia, a nie z jego końcem ${ }^{12}$.

W rezultacie, odpowiadając na pierwsze z postawionych pytań, wskazać należy, że w razie ogłoszenia upadłości posiadacza odpadów (lub władającego powierzchnią ziemi, na której się one znajdują) obowiązek stwierdzony w art. 26 ust. 1 u.o. będzie musiał spełnić syndyk, a nie upadły. Obowiązek ten przejdzie na syndyka już w dniu ogłoszenia upadłości, nawet jeśli postanowienie jeszcze nie będzie prawomocne. Wynika to $\mathrm{z}$ omówionego już przepisu, zgodnie z którym z dniem ogłoszenia upadłości upadły traci prawo do zarządu całym swoim majątkiem. Tym samym nie może usunąć odpadów z miejsca nieprzeznaczonego do ich składowania lub magazynowania ani zlecić ich usunięcia odpowiedniemu podmiotowi za stosownym wynagrodzeniem. Od dnia, kiedy sąd ogłosi upadłość posiadacza odpadów, władny do zrealizowania powyższego obowiązku będzie wyłącznie syndyk.

\section{Postępowanie w sprawie wydania decyzji o usunięciu odpadów}

Jak wskazuje art. 26 ust. 2 u.o., w razie nieusunięcia odpadów zgodnie z ust. 1 wójt, burmistrz lub prezydent miasta, na mocy decyzji wydawanej z urzędu, nakazują ich posiadaczowi usunięcie owych odpadów, z wyjątkiem sytuacji opisanych w tym unormowaniu. $Z$ kolei art. 144 ust. 1 i 2 pr.up. stanowi, że po ogłoszeniu upadłości podmiotu postępowania sądowe, administra-

z masy upadłości. Wydawnictwo C.H. Beck, Warszawa 2010, s. 29; A. Hrycaj: Syndyk masy upadtości. Wydawnictwo WSKiZ, Poznań 2006, s. 111; A. Jakubecki, w: A. Jakubecki, F. Zedler, Prawo upadłościowe i naprawcze. Komentarz. LEX 2010.

${ }^{11}$ Wyrok SN z dnia 6 sierpnia 1998 r., sygn. I PKN 247/98, Legalis nr 43973; wyrok SN z dnia 18 czerwca 2004 r., sygn. II CK 364/03, Legalis nr 63690; uchwała SN z dnia 8 listopada 2006 r., sygn. III CZP 82/06, Legalis nr 78818.

${ }_{12}$ Według odmiennego stanowiska datę ogłoszenia upadłości ustala się według daty i godziny wydania postanowienia przez sąd (P. Feliga: Data ogłoszenia upadtości. Glosa do wyroku Sadu Okręgowego w Toruniu z 13.09.2010 r., VI Ga 9/10. „Monitor Prawniczy” 2011, nr 14, s. 783). Za tym stanowiskiem ma przemawiać art. 51 ust. 1 pkt 7; zgodnie z nim, jeżeli upadły jest uczestnikiem podlegającego prawu polskiemu lub prawu innego państwa członkowskiego systemu płatności lub systemu rozrachunku papierów wartościowych w rozumieniu ustawy, o której mowa w art. 22 ust. 1 pkt 4, lub niebędącym uczestnikiem podmiotem prowadzącym system interoperacyjny w rozumieniu tej ustawy, w postanowieniu o ogłoszeniu upadłości oznacza się godzinę wydania postanowienia. Jednak pogląd ten nie znajduje akceptacji większości komentatorów ustawy Prawo upadłościowe. 
cyjne lub sądowoadministracyjne dotyczące masy upadłości mogą być wszczęte i prowadzone wyłącznie przez syndyka albo przeciwko niemu. Postępowanie w sprawie decyzji, o której mowa w art. 26 ust. 2 u.o., syndyk prowadzi na rzecz upadłego, z zastrzeżeniem, że działa w imieniu własnym. Stroną zaś jest właśnie dlatego, że masa upadłości, będąc przedmiotem stosunków cywilnoprawnych, nie może być ich podmiotem ${ }^{13}$. W sprawie, w której syndyk działa na rzecz upadłego, świadczenie dochodzone przez syndyka lub przeciwko niemu podlega zasądzeniu na rzecz upadłego lub od upadłego ${ }^{14}$.

Stwierdzenie ustawodawcy, że syndyk jest stroną w postępowaniach dotyczących masy upadłości, oznacza, iż przysługuje mu legitymacja do występowania $\mathrm{w}$ tych postępowaniach. Niemniej jest to strona w znaczeniu wyłącznie formalnym, ponieważ syndyk działa $\mathrm{w}$ imieniu własnym. W znaczeniu materialnym stroną pozostaje upadły, będący podmiotem stosunku prawnego, którego dotyczy postępowanie. Sam nie posiada jednak legitymacji procesowej (formalnej), nie może więc działać osobiście, zatem czyni to za niego syndyk ${ }^{15}$. Co istotne, tego ostatniego nie należy oznaczać z imienia i nazwiska jako strony procesu, ,[s]yndyk bowiem w postępowaniach dotyczących masy upadłości występuje jako organ postępowania upadłościowego, a nie jako konkretna, zindywidualizowana w wyroku osoba"16.

Kiedy prowadzone jest postępowanie w sprawie usunięcia odpadów z miejsca nieprzeznaczonego do ich składowania, wszelkie pisma i orzeczenia trzeba doręczać syndykowi, gdyż właśnie on działa na rzecz upadłego i na jego rachunek $^{17}$. „Jeśli sąd pierwszej instancji proceduje $\mathrm{z}$ udziałem upadłego, a nie $\mathrm{z}$ udziałem syndyka, wydany $\mathrm{w}$ takich warunkach wyrok dotknięty jest wadą nieważności”18. Niezawiadomienie syndyka o wyznaczonej rozprawie sądowej musi być uznane za pozbawienie go możności obrony w postępowaniu praw upadłego ${ }^{19}$. „W myśl art. 52 pr.up. data wydania postanowienia o ogłoszeniu upadłości jest datą upadłości. Oznacza to, że skutki, jakie wiążą się z ogłoszeniem upadłości, następują w dniu ogłoszenia upadłości, bez względu na to, kiedy orzeczenie to zostanie obwieszczone w »Monitorze Sądowym i Gospodarczym«, odnotowane w rejestrze przedsiębiorców Krajowego Rejestru Sądowego, a także [...] kiedy organ prowadzący postępowanie uzyska o tym zdarzeniu

${ }^{13}$ W. Broniewicz: Stanowisko syndyka upadłości w procesach z jego udziałem. „Państwo i Prawo" 1993, nr 2, s. 45.

${ }_{14}$ Wyrok SN z dnia 7 października 2004 r., sygn. IV CK 86/04, Legalis nr 67325.

15 Wyrok WSA w Krakowie z dnia 6 czerwca 2013 r., sygn. I SA/Kr 1878/11, Legalis nr 865076.

${ }^{16}$ D. Chrapoński, w: Prawo upadłościowe. Komentarz. Red. A.J. Witosz. LEX 2017, art. 144 .

${ }^{17}$ R. Adamus: Prawo upadtościowe..., s. 548-549.

18 Wyrok NSA z dnia 11 kwietnia 2018 r., sygn. I FSK 820/16, LEX nr 2494599.

${ }^{19}$ Wyrok NSA z dnia 10 września 2009 r., sygn. I FSK 921/08, Legalis nr 215528. 
wiedzę" ${ }^{20}$. Decyzja wchodzi do obrotu prawnego z chwilą jej skutecznego doręczenia adresatowi, natomiast bez znaczenia pozostają okoliczności jej nadania. W takiej sytuacji po powzięciu informacji o ogłoszonej upadłości obowiązkiem organu pierwszej instancji jest ponowne doręczenie decyzji syndykowi i dopiero od tego zdarzenia należy liczyć termin do wniesienia odwołania ${ }^{21}$.

Zgodnie z powyższym przyjąć zatem trzeba, że osobą obowiązaną do usunięcia odpadów z miejsca nieprzeznaczonego do ich składowania będzie syndyk masy upadłości posiadacza odpadów. $\mathrm{W}$ postępowaniu, o którym mowa w art. 26 ust. 2 u.o., będzie on działał we własnym imieniu, ale na rzecz upadłego. Zasadność decyzji zobowiązującej do usunięcia odpadów i jej ewentualne zaskarżenie powinny być ocenianie przede wszystkim (oprócz kwestii wymagań procesowych) przez pryzmat osoby upadłego i spełnienia przez niego przesłanek wskazanych $\mathrm{w}$ art. 26 ust. $1 \mathrm{w}$ związku z art. 3 ust. 1 pkt 19 u.o. Jednocześnie podkreślenia wymaga, że syndyk nie może obalić domniemania z art. 3 ust. 1 pkt 19 u.o., powołując się na okoliczność, że nie jest wytwórcą ani posiadaczem odpadów, gdyż powstały one i zostały zdeponowane na terenie nieruchomości, której posiadaczem jest upadły, przed dniem ogłoszenia jego upadłości. Jak już nadmieniono, w postępowaniach dotyczących masy upadłości syndyk jest stroną $\mathrm{w}$ znaczeniu wyłącznie formalnym, natomiast $\mathrm{w}$ znaczeniu materialnym stroną pozostaje upadły. Tym samym ustalenie, że odpady zalegały na danej nieruchomości jeszcze przed datą ogłoszenia upadłości, nie wpływa na obowiązki wynikające $\mathrm{z}$ art. 26 ust. 1 i 2 u.o.

\section{Podsumowanie}

Z dniem ogłoszenia upadłości upadły traci prawo zarządu mieniem wchodzącym do masy upadłości oraz możliwość korzystania z niego i rozporządzania nim. Jednocześnie zarząd ten przejmuje syndyk, który od dnia ogłoszenia upadłości zamiast upadłego posiadacza odpadów staje się odpowiedzialny za ich usunięcie zgodnie $\mathrm{z}$ art. 26 ust. 1 u.o. W razie wszczęcia lub prowadzenia postępowania $\mathrm{w}$ sprawie wydania decyzji, o której mowa w art. 26 ust. 2 u.o., od dnia ogłoszenia upadłości stroną postępowania staje się syndyk i to on będzie ewentualnie obowiązany do wykonania owej decyzji.

${ }^{20}$ Wyrok WSA w Rzeszowie z dnia 9 października 2018 r., sygn. I SA/Rz 317/18, Legalis nr 1834865.

${ }^{21}$ Wyrok WSA w Rzeszowie z dnia 18 października 2018 r., sygn. I SA/Rz 323/18, Legalis nr 1834593. 


\title{
Literatura
}

Adamus R.: Prawo upadtościowe. Komentarz. Wyd. 2. Wydawnictwo C.H. Beck, Warszawa 2018.

Broniewicz W.: Stanowisko syndyka upadłości w procesach z jego udziatem. „Państwo i Prawo” 1993, nr 2, s. 41-49.

Chrapoński D., w: Prawo upadłościowe. Komentarz. Red. A.J. Witosz. LEX 2017.

Chrapoński D.: Wyłaczenia z masy upadtości. Wydawnictwo C.H. Beck, Warszawa 2010.

Feliga P.: Data ogłoszenia upadtości. Glosa do wyroku Sadu Okregowego w Toruniu z 13.09.2010 r., VI Ga 9/10. „Monitor Prawniczy” 2011, nr 14, s. 783-788.

Gurgul S.: Prawo upadtościowe. Prawo restrukturyzacyjne. Komentarz. Wyd. 12. Legalis 2020.

Gurgul S.: Realizacja obowiazku ochrony środowiska w postępowaniu upadtościowym przedsiębiorcy. „Monitor Prawniczy” 2019, nr 12, s. 673-680.

Herapolitańska I., Tułodziecka A., Hryćków-Mycka K.: Komentarz do wybranych przepisów Prawa upadłościowego. W: Ustawa o księgach wieczystych i hipotece oraz przepisy zwiazane. Komentarz. Wyd. 4. Legalis 2019.

Hrycaj A.: Syndyk masy upadtości. Wydawnictwo WSKiZ, Poznań 2006.

Jakubecki A., w: A. Jakubecki, F. Zedler: Prawo upadlościowe i naprawcze. Komentarz. LEX 2010.

Janda P.: Prawo upadtościowe. Komentarz. Wyd. 2. LEX 2020.

Zimmerman P.: Prawo upadtościowe. Prawo restrukturyzacyjne. Komentarz. Wyd. 6. Legalis 2020.

Jaoanna Szymańska-Jochemczyk

\section{The declaration of bankruptcy of the waste possessor versus responsibility of waste disposal from a place not intended for their storage in the light of waste regulations}

\author{
Summary
}

The hypothetical situation where a waste possessor, obliged to waste disposal from a place not intended for its storage, is in bankruptcy - is the main aim of this paper. Particularly, the work is dedicated to determine the entity obliged to fulfil this obligation also in case of initiating appropriate proceedings.

Key words: the bankruptcy of the waste possessor, receiver, waste disposal 
Иоанн Шиманьска-Иохемчик

\section{Объявление банкротстве владельца отходов и обязательство их удаления из места, не предназначенного для складирования, в соответствии со ст. 26 \ и 2 Закона об отходах от 4 декабря 2012 года}

Резюме

Предметом статьи является анализ гипотетической ситуации, в которой в отношении владельца отходов, обязанного удалить их из места, не предназначенного для хранения, ведется процедура банкротства. В частности, работа посвящена установлению лица, ответственного за выполнение этого обязательства, также в случае объявления соответствующей процедуры.

Ключевые слова: банкротство владельца отходов, синдик, удаление отходов

Joanna Szymańska-Jochemczyk

\section{Dichiarazione di fallimento di un detentore di rifiuti contro l'obbligo di rimuovere i rifiuti da un luogo non destinato al loro stoccaggio alla luce dell'articolo 26, paragrafi 1 e 2 della legge sui rifiuti del 14 dicembre 2012}

Sommario

L'oggetto dell'articolo è l'analisi di una situazione ipotetica in cui un detentore di rifiuti obbligato a rimuovere i rifiuti da un luogo non destinato al loro stoccaggio è in fallimento. In particolare, il documento si concentra sulla determinazione della persona che è competente per eseguire l'obbligo di cui sopra anche nel caso di apertura di un procedimento appropriato.

Parole chiave: fallimento di un detentore di rifiuti, fiduciario, smaltimento dei rifiuti 